\title{
Utilizing Image Media to Develop Early Language Capabilities in Children
}

\author{
Thresje Tolukun \\ Department of Early Childhood Teacher Education \\ Universitas Negeri Manado Tomohon, North Sulawesi, Indonesia \\ treistolukunfip@gmail.com
}

\begin{abstract}
The purpose of this research is to Utilize Image Media to Develop Language Skills in Kindergarten Permata Bunda Manado Kindergarten. Media are all items used in teaching and learning activities so that they can stimulate smoothly, orderly, and efficiently so that the goals of early childhood education can be achieved. The use of instructional media or educational media to improve children's learning abilities, especially for early childhood, will greatly affect the ability of gross motor skills and fine motor skills of early childhood. Media that can be used to stimulate thoughts, feelings, attention, and the ability or learning skills so that it can encourage the learning process. This study uses four stages, namely Planning, Acting, Observation, Reflection. The research subjects were 16 children. Cycle I Research Results obtained 6 (37\%) of the 16 children in learning batik clothing. in cycle II an increase in children's learning success obtained 13 (82\%) and was declared successful. The results of this study concluded that the use of Image Media Utilization was able to Develop Children's Language Ability in Kindergarten Class Permata Bunda Manado.
\end{abstract}

Keywords: Image Media, Language Ability, Early Childhood

\section{INTRODUCTION}

Early childhood education plays a very important role in children's development, because it is a basic foundation in the child's personality. Children aged 5-6 years have a very rapid period of intelligence development. So, the present is called the golden age (golden age). This period is the first basic period in developing various activities, in order to develop children's potential from an early age, experts say as the golden age of its development. To boost this development potential, every child needs a balanced nutritional intake of health protection, loving care, and stimulation. Education must be in accordance with the stages of development and abilities of each child.

Daryanto (2001) said the provision of educational stimuli can be done from birth, even since they are still in the womb. This educational stimulus should be done in stages, repeatedly, consistently, and thoroughly so that it has the effort for children. Education is a conscious and planned effort to create an atmosphere of learning and learning process so that students effectively develop their potential to have the spiritual, religious, self-control, personality, intelligence, and skills needed by themselves and the community. Education includes the teaching of special expertise and also something that can be seen but more deeply the provision of knowledge, consideration and wisdom.

Speaking especially speaking is needed as a basis for children to interact with others, both with their parents and with their peers and people who are more mature than themselves. Language for children is also very important, language skills are learned and acquired by early childhood naturally to adapt to their environment, as a social tool, language is a way to respond to people. According to Jamaris (2005) aspects relating to children's language development include: vocabulary, cyst axis (grammar), and sematic (use of words according to their purpose).
For this reason, there are several determinants in increasing language creativity for early childhood. One of them is the use of drawing media to develop children's language skills, the use of images varies greatly: some use star images, vegetation or fruit images. By using a variety of images, the child is challenged to recognize the picture shown to the child, after the child recognizes the picture being seen, the child will mention what the name of the picture that was shown to him. In using images, children are required to mention what images they see, so as to achieve children's language creativity.

Engkoswara (1992) explained that drawing media is a tool for the equipment used by the teacher in communicating with students in the learning process more effectively and can increase children's enthusiasm for learning. Children can certainly understand what they are learning, if they learn continuously for a long time. Image media are also used to channel messages and can stimulate children's thoughts, feelings, attention, and willingness in learning that encourages good learning. From the description above, researchers need to conduct research on improving children's language creativity through the use of media images in kindergarten Permata Bunda Manado.

The word media comes from the Latin word Medium which literally means middle, intermediary or introduction. In other words, the media is the intermediary or messenger of the message from the sender of the message to the recipient of the message. Gerelach and Sutikno (2013) argued that the media if understood broadly is human. Material or events that build conditions that enable students to obtain knowledge, skills or attitudes. Supratman (Sutikno, 2013) defines the media as a tool used to channel messages or information from the sender to the recipient of the message.

Among educational media, images are the most popular media used. Media is also a common language that can be understood and enjoyed everywhere. 
Therefore, there is a saying that says a picture speaks more than a thousand words. Images are imitations of many rights, for example: people, animals, objects and so on. Made with pencil or other stationery on paper.

Media are all items used in teaching and learning activities so that they can stimulate smoothly, orderly, and efficiently so that the goals of early childhood education can be achieved. The use of instructional media or educational media to improve children's learning abilities, especially for early childhood, will greatly affect the ability of gross motor skills and fine motor skills of early childhood. Media that can be used to stimulate thoughts, feelings, attention, and the ability or learning skills so that it can encourage the learning process.

\section{METHOD}

This study uses the Classroom Action Research (CAR) approach according to the Kemmis and Taggart spiral model (1990) describing the research focus of the study of the problem of learning by using various actions that are threatened in the next situation in the form of analyzing the actions of the learning process. The research used consisted of 4 activity phases: planning, acting, observation, and reflection.

These four stages form a cycle with a spiralshaped research flow. The subject of this research is the children at the Permata Bunda Kindergarten in Manado. The time of the research was carried out for three months starting at the research place in Permata Bunda Manado Kindergarten. Data collection techniques in this study were carried out based on observation, test and documentation guidelines. Research subjects guided by the 2013 PAUD curriculum which have been used in Permata Bunda Manado Kindergarten. with the following categories:

Symbol (BB) (MB) (BSH) (BSB) as a sign of achieving indicators that are in accordance with Permendikbud No. 137 of 2014. Data analysis technique used by researchers in this study is the calculation of the percentage where the researchers calculate the child's ability to reach indicators. And the results of the study can be divided into two types namely qualitative and quantitative data. Qualitative research data is research data in the form of quality or quality of an. Qualitative data is measurement data that will be examined based on quality or quality.

\section{RESULTS}

\section{Cycle I}

Of the 16 children who participated in the learning activities, there were $4(25 \%)$ children who received one star which indicated that the ability of the four children was still categorized as not having the ability to develop children's language skills. Here the children have been classified in their development but have not been able to make a picture of clothes because the child is silent when asked by the teacher, what is on the blackboard. while 6 children $(38 \%)$ received two stars which indicated that the ability of the six children was categorized as developing their ability to make batik clothing, but could not yet develop children's language skills correctly and still needed to be assisted and guided by the teacher in learning activities. then 4 children $(25 \%)$ children get a three-star sign which indicates that the ability of the four children is categorized to develop as expected in terms of honing fine motor skills children develop children's language skills correctly but still need the role of the teacher in time and answer questions from the student. And 2 children (12\%) children get a four star sign indicating that the ability of the two children is categorized as developing very well developing children's language skills which can be interpreted as being able to show how to make a picture of clothing by using group work methods or collaboration with other friends correctly and spontaneously answer teacher questions.

Children who are able in the learning process are those who get three-star and four-star signs, including children's categories which can be said to be successful in making batik clothing by using cooperative learning methods or models. So, in this first cycle there were 6 children $(38 \%)$ children who succeeded, from the number of children who experienced a good development in terms of batik clothing drawings from the target of $80 \%$. This shows that this research must be continued in the next cycle.

\section{Cycle II}

Of the 16 children who take part in learning activities, there is no child who gets an I star, which means that the student has been able to develop their language skills. Here the children have been classified in their development, but in developing their language skills. The results obtained by 3 children (18\%) children get two stars which shows that the ability of the three children is categorized as developing ability to develop children's language skills. but have not been able to develop children's language skills correctly, then 6 children (38\%) children get a three-star sign which indicates that the child's ability to categorize developing according to expectations in terms of honing the child's fine motor skills in developing children's language skills. correctly but still requires the teacher's role in time and answers the question of the student.

And 7 children (44\%) children get a four-star sign which shows that the ability of the two children is categorized as developing very well in developing children's language skills. which can be interpreted that can already show how to develop children's language skills. by using group work methods or collaboration with other friends correctly and answering the teacher's questions spontaneously. Children who are able in the learning process are those who get three-star and four-star signs, including children's categories which can be said to be successful in developing children's language skills. So, in this first cycle there were 16 children $(82 \%)$ children who succeeded, from the number of children who experienced good development in developing children's language skills from the target of $80 \%$. Which means this research does not need to be continued in the next cycle.

\section{DISCUSSION}

Discussion of research results is directed at the implementation of the research cycle I and cycle II by following the 4 stages of research, namely planning, 
implementing actions, observing and reflecting. With the implementation of classroom action research using cooperative learning models to improve the ability to make batik pictures of children in Permata Bunda Kindergarten 2018-2019 Academic Year turns out to be very satisfying results.

The results of children's learning in the first cycle of learning there are 4 children (25\%) children get a star sign which means that the four children are categorized as not yet having the ability to develop children's language skills. To improve their ability to develop their language abilities. child language. This shows the need to hold special guidance in learning activities. Then there are 6 children (38\%) children get two stars, which means that the six children are categorized as developing abilities in developing children's language skills.

In this case they can already develop children's language skills. but still having difficulty in honing the fine motor can be interpreted the child still needs to be guided and guided by the teacher in his learning activities. Furthermore, 4 children (25\%) received a three-star sign which indicated that the four children were categorized as developing according to expectations in terms of developing children's language skills, which means they were able to develop children's language skills. by following the steps and ways presented by the teacher in learning but still growing time to answer the teacher's questions, so learning must be repeated to improve the child's developmental abilities.

And 2 children (12\%) received four-star signs that both children had the ability to develop children's language skills correctly and were able to answer the teacher's questions spontaneously even though this child had shown good progress in developing language skills child. correctly and quickly by following the steps and ways taught by the teacher in learning activities.

Children who received one star and two stars were declared unsuccessful in participating in learning activities in cycle I. In this case there were $10(63 \%)$ children out of 16 children who had not shown good development in terms of developing children's language skills. Then the learning outcomes of children in children who get three stars and four stars were declared successful following the learning activities in this first cycle. Thus there are $6(37 \%)$ children out of 20 children who are declared successful because they have shown the development of abilities in developing children's language abilities so that the results of children's learning achievements are only about $37 \%$ of the target of $80 \%$ so this class action research needs to be continued in the next cycle.

\section{CONCLUSION}

Based on the results of research that has been carried out by giving some actions from the first and second cycles as well as the discussions that have been carried out, it can be concluded that how the use of image media to develop children's language skills in TK Permata Bunda Manado Kindergarten class. This is seen from the results of research carried out in cycle I has increased in the implementation of learning in cycle II.

The results of the first cycle of classroom action research have not been successful with an average learning achievement of 6 children $(37 \%)$ out of 16 children, with a target of $80 \%$ success so that classroom action research in developing children's language skills. Continue on the next cycle. And the results of the second cycle of classroom action research have increased so that it was declared successful with an average learning achievement that includes the success of 13 children $(82 \%)$ of 16 children with a target of $80 \%$ learning success.

Because this learning model teaches children to collaborate with other groups. How to use image media to develop children's language skills in the Permata Bunda Manado Kindergarten class. appropriate learning to be applied in class in accordance with the objectives of each learning to be carried out.

\section{REFERENCES}

[1] Jihad. 2008. Penilaian Hasil Proses Belajar Mengajar. Bandung : P.T Remaja Rosdakarya

[2] Oemar Hamalik. 2003. Proses Belajar Mengajar. Jakarta: Bumi Aksara.

[3] Sanjaya,Wina. 2008. Strategi Pembelajaran. Kencana: Jakarta

[4] Sudijono, Anas. 2010. Pengantar Statistik Pendidikan. Jakarta : Rajawali Pers

[5] Sudjana, Nana. 2006. Penilaian Hasil Proses Belajar Mengajar. Bandung: PT Remaja Rosda Karya.

[6] Sudjana. Nana. 2006. Penilaian Hasil Proses Belajar Mengajar. Bandung : PT Remaja Rosda Karya.

[7] Sudjiono, 2007. Kriteria Penilaian Hasil Belajar. Kencana: Jakarta.

[8] Sugiyono. 2012. Metode Penelitian Pendidikan (pendekatan kualitatif, kuantitatif, dan R\&B). Bandung: Alfabeta.

[9] Suparno. 2006. Artikel Penelitian Tentang Model Pembelajaran Inquiri. Jakarta: Rineka Cipta.

[10] Suprijono, Agus. 2009. Cooperatif Learning Teori dan Aplikasi PAIKEM. Surabaya : Pustaka Pelajar.

[11] Trianto. 2009. Mendesain Model Pembelajaran InovatifProgresif. Jakarta: Balai Pustaka

[12] Usman, dkk. 2008. Penelitian Tindakan Kelas. Darussalam: Universitas Syiah Kuala.

[13] W. Gulo. 2008. Strategi Belajar Mengajar. Jakarta: Gramedia Widisarana Indonesia.

[14] Wardhani,I. Kuswaya Wihardit, 2008. Penelitian Tindakan Kelas, Jakarta: Universitas Terbuka

[15] Yus, Anita.2005. Penilaian Perkembangan Belajar Anak Taman Kanak-Kanak. Jakarta: Diretur Pembinaan Pendidikan Tenaga Kependidikan dan Ketenagaan Perguruan Tinggi. 